\title{
Technology-Based Language Learning: Investigation of Digital Technology and Digital Literacy
}

\author{
Hussien Mohamad Alakrash (D) and Norizan Abdul Razak* \\ Center for Research in Language and Linguistics, Faculty of Social Sciences \& Humanities, \\ Universiti Kebangsaan Malaysia, Bangi 43600, Malaysia; hussienalakrash94@gmail.com \\ * Correspondence: norjef@ukm.edu.my
}

check for updates

Citation: Alakrash, H.M.; Abdul Razak, N. Technology-Based Language Learning: Investigation of Digital Technology and Digital

Literacy. Sustainability 2021, 13, 12304 https://doi.org/10.3390/ su132112304

Academic Editors: Osamah

Ibrahim Khalaf, Kingsley A. Ogudo and Vitaliy Mezhuyev

Received: 17 September 2021

Accepted: 26 October 2021

Published: 8 November 2021

Publisher's Note: MDPI stays neutral with regard to jurisdictional claims in published maps and institutional affiliations.

Copyright: (c) 2021 by the authors. Licensee MDPI, Basel, Switzerland. This article is an open access article distributed under the terms and conditions of the Creative Commons Attribution (CC BY) license (https:/ / creativecommons.org/licenses/by/ $4.0 /)$.

\begin{abstract}
The use of digital technologies in developing the four language skills in English classrooms has not been sufficiently researched. Furthermore, the COVID-19 pandemic has highlighted the importance of digital technology and digital literacy in teaching and learning English. This study aims to firstly investigate the applications of digital technology and the level of digital literacy in learning and teaching English. Secondly, to measure the significant differences between EFL teachers and students in their usage of technology and digital literacies in English classrooms. Two questionnaires were distributed to 150 students and 40 teachers. The data were analyzed descriptively using SPSS 23.0. The findings show that students' use of digital technology was the highest in learning vocabularies and lowest in reading skills, while teachers' highest use was for general teaching practices and lowest for reading skills. Participants have high digital literacies. The findings supported the null hypotheses related to the significant difference between usage of digital technology for language pedagogy. These findings offer implications for policymakers towards designing plans to integrate digital technologies in the language classrooms of marginalized societies such as B40 in Malaysia.
\end{abstract}

Keywords: digital technology; technology-based learning; English learning; English teaching; Malaysia; fourth industrial revolution (4.0)

\section{Introduction}

The increasing acceptance of digital technology has necessitated the promotion of foreign language learning and teaching, especially in areas where there is inadequate exposure to genuine resources and materials. Contemporary digital technologies, as per [1] have become powerful avenues for the teaching and learning of languages. Nowadays, electronic means of learning foreign languages have become the most appealing to the digital natives' needs. Digital technologies have impacted various aspects of language learning, such as modern learning management systems [2] autonomous, self-paced, collaborative learning, as well as socio-constructivist target-language acquisition. For these aspects of language learning, the common ground remains the central premise of communicative language teaching; i.e., learning by participating/doing rather than just dictating [3,4].

Increasingly, the English language as a lingua franca has become the dominant language throughout the world. Globally, the English language is currently the most common language of communication amongst people of different first languages in the field of business, commerce and the sciences as well as in academia. In the EFL context, the increasing relevance of the English language can also be recognized in the employment and education sectors [5] and in consideration of the relevance of the English language in the EFL context, new language policies have been introduced by the governments such as the Saudi government, which demands that all students both at the high and the intermediate school levels to compulsorily study the English language [6]. The English language has also become the mode of teaching in most Arab schools [7]. However, despite the great commitment of the 
governments to this course in terms of policies and spending, the English language skills of the students remains at a basic level [8]. Consequently, this has exacerbated the already difficult task of using the English language as a means of communication, thereby having negative impacts on the ability of the students to complete their studies. In consideration of this stance, E-learning has been introduced at the intermediate and high school levels by the Ministry of Education (MoE), to serve as an additional tool for studying English as a Foreign Language (EFL) [9].

Technological innovations have revolutionized many sectors of human endeavor, but its acceptance in the English language teaching and learning sector for the facilitation of teaching and learning still faces various challenges [10]. For instance, the use of technologies in the EFL classroom has only been restricted to a didactic manner of teaching and learning in which teaching is based on the provision of electronic teaching materials using personal computers [11,12]. However, digital technology, the driving force of the fourth industrial revolution (4IR), is far beyond the use of computers and e-materials, as its effectiveness in improving the learning experience demands compatibility with the learner-centered approach [13]. With the rapid diffusion of the much-anticipated 4IR, it is expected that there will be an impact on not just the economy but also on education [14].

The extent of technology use is in EFL classrooms is currently low due to its costs, lack of training, and perceived limited application, and in the EFL classroom, its effectiveness is not well documented. For a better understanding of the relevance of the 4IR in promoting teaching and learning practices, it is important to have proper knowledge of the various components of the 4IR. Levy [15] highlighted the "need for sustained reflection on pedagogy in technology-based teaching and learning of new languages, as well as assessment of the extended usage and relevance of older and newer technologies which are considered important for language learning" (p. 779). Based on the existing categories of the 4IR, it is believed that its adoption is not restricted to computer usage, especially in the education sector; it may involve other aspects, such as the development of a platform that will encourage information sharing and data analytics for a better understanding of the teaching needs of the learners in learning the English language.

The increasing acceptance of digital technology has also necessitated the promotion of foreign language learning and teaching, especially in areas where there is inadequate exposure to genuine resources and materials. These studies highlighted a great deal of positive pedagogic impacts, such as time-cost consumption, personalized learning, motivation, etc. The evidence in the literature also suggests the collaborative support of digital technology towards learning the English language. Furthermore, the literature evidence suggests that more attention has been given to technology-based uses in English language teaching (ELT) in general, while little attention has been given to technologybased language teaching and learning, especially in the Arab EFL context. The implication is that numerous studies have been dedicated to technology-based teaching and learning in the Arab contexts, but in the current context, the feasibility of technology-based teaching and learning in international Arabic schools is yet to be fully studied, owing to the lack of sufficient data in the fully explored areas.

However, in consideration of the few studies that have focused on the use of digital technologies in the Arab international schools in Malaysia, it has become necessary to study the use and the digital literacies in using digital technologies by EFL teachers and students in EFL classrooms. This area demands investigation as it will guide the identification of the factors associated with the use of digital technologies in language education. One issue that has been much discussed is whether there are linguistic gains associated with the use of technology [16]. Controversial issues, such as the benefits of digital technology exposure to L2 and ICT-based English discourse demands further investigation. The contributions of technology towards greater exposure to English should also be considered, since the quantity and quality of exposure matters when it comes to language acquisition [17]. Debates are still ongoing on how technology-based inputs should be measured. Based on the reviewed studies, it is clear that most of the relevant areas of the phenomenon are yet 
to be fully understood. It is also believed that digital technologies have more to offer to the teaching and learning of EFL.

The spread of digital content following COVID-19 has exposed students to a vast amount of information through digital technologies [18]. More than ever before, teachers and students are in crucial need of the digital-literacy skills that would allow them to identify the nature of the information they are surrounded by; find out if it is useful and credible; and protect themselves from lagging in the education process [19]. During COVID-19, the main reason for lagging behind is lacking of digital literacy among teachers and students. Teachers and students who lack digital-literacy skills may soon find it difficult to gain access to information available online. For effective use of digital technologies in the field of language teaching and learning, students must be competent in the use of such technologies; they need to have the necessary digital literacies for effective exploitation of the digital environment [20]. The rising use of digital technology in society means that there is an inevitable need for digital literacy among students, in order for them to succeed both in academic and professional life. This mainly depends on the ability of the teachers to appropriately and effectively deploy such technologies for educational purposes [21]. Educators must be digitally literate in order to help students in participating towards bridging the digital skills gap in the modern digital age and creating an agile learning environment. In terms of teaching and learning English as a foreign language (EFL), digital literacies are of utter importance as they provide teachers and students with a variety of information about linguistic discourses, language structures, pronunciation, and grammatical patterns [22]. Hence, keeping with this new trend demands that language teachers must strive to improve the existing technological competencies of their students, especially in the use of modern digital technologies for language learning. School administrators also play important role in developing students' digital literacies [23]. However, how teachers and administrators improve their student's digital literacies is still unrevealed. Thus, this study will fill this gap in the literature by investigating the strategies of teachers and administrators in enhancing students' digital literacy.

Although the study was inspired by previous studies, it is distinct from those studies in some ways. To begin with, it is carried out by a local researcher who is primarily an EFL teacher, familiar with the scenario of TEFL in the local context. Being an EFL teacher at two of the target schools, the researcher brought to the inquiry practical and personal experiences and insightful approaches to the research problem. Moreover, in terms of methodology, the bulk of the previous studies (cited above) adopted monomethod approaches which are insufficiently versed to examine the breadth of an issue of such a complex nature. By adopting a mixed-method approach, the study at hand accounts for an elaborated examination of the phenomenon under consideration. A mixed-method design has the capacity to produce more comprehensive answers to the research questions than a pure method alone would. Besides, whereas previous studies measured the impacts of digital technologies on language learning by using the individuals' stated perceptions (a proxy view of technology), this study, by triangulating methods of data collection, expands the procedures of measuring the phenomenon: surveying the informants' use of digital technologies using a self-reporting survey.

\subsection{Fourth Industrial Revolution and Language Education}

The World Economic Forum (WEF) yearly gathering, which occurred in Davos, Switzerland in 2016, featured the purported Fourth Industrial Revolution as one of the most pivotal topics that will be found in the years to come [24]. There was an exceptionally solid sense that society is on the cusp of mechanical improvements that will, in a general sense, change how we live and will change business, markets and the worldwide economy. As the world moves into the Fourth Industrial Revolution (4IR; characterized as an advanced upheaval joining the physical, computerized, and natural aspects that are affecting the world), there is a desire to move quickly, for nations to utilize 4IR innovations for economic improvement and to offer types of assistance to improve the personal satisfaction for all 
residents. Gap [25], commenting on The World Economic Forum (2017) announced that the 4IR is changing the world because new advancements that join the physical, computerized, and organic universes are affecting all controls, economies, and businesses. As per Schwab [24], 4IR is more than innovative progression; it is a change that is affecting various divisions of society. Industry 4.0 is the current mechanical change, with computerization, information trades, cloud, digital-physical frameworks, robots, Big Data, AI, IoT and (semi-)independent modern strategies being used to understand the new advances and development.

Many fields, including the educational domain, are conflicting in their adaptation to the fast spread of technology. Lacking consistent application in the use of technology in education, there is no clear proof about organizational educating [26]. The technology of 4IR has concentrated on computers especially in producing products; however, there are not many studies about the industry and educating sectors [27]. There is not a lot of research that studied the aspects of important stakeholders to show the ability of 4IR in changing the processes of the domain. On the other hand, there is a study that examined the points of view of Australian students about the use of modern innovations in "technology" in education at universities [26], and they clarified that the use of modern technology may support self-study, but they noticed that the use of technology does not affect education in higher educational organizations. The educational domain faces some problems since it is not receptive to $4 \mathrm{IR}$. The problem is how to help graduated learners to be innovative in their concepts in the world of technology. It will require a lot of time to make the educational domain depend on 4IR more than the use of computers in teaching and learning. The educational domain will benefit from the technology revolution, and the importance of the use of technology in teaching and learning will be shown.

\subsection{English Language and Technology}

The use of technology helps to make information reciprocal among people, and it helps to keep information safe. Digital technologies consist of hardware and software. The digital technologies consist of developed technologies including laptops, digital libraries, and the WWW. The English language has been used as the main language in technology. English and technology are used in international communication; for example, English is learned by EFL [28]. Being able to use English helps to achieve success in many fields such as economics and politics. Students can be professionals in technology when they are good at English and know how to use computers, assuring the concept that being good in modern technology requires one to be good at English; as a result, there will be increased experience in the scope of technology.

Because of the excessive use of digital technologies inside and outside school, the function of the tutors is altering in the classroom. According to Jenkins (2009), when new kinds of technology appear, the relations between the tutor and the student and their relations with the conventional instruments such as "rulers, pencils, and pens" will be changed. Ertmer \& Ottenbreit-Leftwich [29], have declared that the experience of the teacher has a significant role in making decisions. Additionally, teachers should try to increase their experiences to develop their way of teaching. The knowledge of the teacher includes his experience in the subject he teaches and teaching methodology. Additionally, teachers should have a particular experience about a particular subject matter to teach it to particular students within a particular situation. According to [30], teachers should have extra knowledge, and this knowledge should be mixed with their schema to be able to use modern technology.

Having experience in hardware and software is not enough to achieve professional teaching. The relationship between teaching methodology, technology, and the subject matter should be taken into consideration. Teachers should have enough experience with every tool so that they can teach specific subject matters easily. Therefore, the use of technology may provide some beneficial consequences for the learners. Moreover, tutors need to have good experience with the teaching methods and about the subject matter 
that they want to teach to provide their information professionally to their learners. On the other hand, [31] referred to the point that tutors have some difficulties in learning technology. The tutor's need to keep up with the changes in the field of technology is like hitting a moving target [29] (p. 250). Consequently, tutors will always need to keep up with modern technologies, but this is difficult for them.

Policymakers, researchers, language learners, and teachers can rely on the outcome of this study when planning to adopt new technologies that can assist language learning; this study provides information on the latest technologies, their advantages, and challenges, as well as the manner of their application to language teaching and learning.

\section{The Current Study}

A more critical and in-depth look into the use of digital technologies in terms of usage in English language teaching and learning should be conducted. In addition, instead of measuring such factors separately, these factors will be measured in a single study. Hence, the study aims to achieve the following research questions.

\subsection{Research Questions}

1. What is the use of digital technologies for learning and teaching English language purposes?

2. What is the level of digital literacy among EFL teachers and students?

3. Is there a significant difference between teachers' and students' use of digital technologies for teaching and learning purposes?

\subsection{Hypotheses of the Study}

The study used null hypotheses based on the new assumption that teachers and students have acquired adequate knowledge and literacies of using digital technologies as the data were gathered in the post-COVID19 pandemic era, where teaching and learning were technology-based.

Hypothesis 1 (H1). There is no significant difference between students' and teachers' use of technologies for general learning/teaching purposes.

Hypothesis 2 (H2). There is no significant difference between students' and teachers' use of digital technologies in teaching or learning listening.

Hypothesis 3 (H3). There is no significant difference between students' and teachers' use of digital technologies in learning or teaching speaking.

Hypothesis 4 (H4). There is no significant difference between students' and teachers' use of digital technologies in learning or teaching writing.

Hypothesis $\mathbf{5}$ (H5). There is no significant difference between students' and teachers' use of digital technologies in learning or teaching vocabularies.

Hypothesis 6 (H6). There is no significant difference between students' and teachers' use of digital technologies in learning or teaching reading.

Hypothesis 7 (H7). There is no significant difference between students' and teachers' basic digital-literacy skills.

Hypothesis 8 (H8). There is no significant difference between students' and teachers' didactic digital-literacy skills. 


\section{Materials and Methods}

\subsection{Research Design}

A fully quantitative research design using the descriptive approach was used for the current study. This study was conducted due to the unsatisfactory use of digital technologies in the EFL classroom. Due to this fact, this study is intended to investigate the use of digital technologies and digital literacy among Arab EFL teachers and students. The study was conducted in Malaysia, and the researcher collected the data from selected Arab international schools in Malaysia.

\subsection{Sample and Sampling}

A total number of 150 students were sampled using the proportional random method suggested by Krejcie \& Morgan [32], and 40 EFL teachers were selected using census sampling. Informed consent for participation was obtained from the participants. E-mails were sent to the participants asking them whether they were willing to participate. The survey method was followed to collect the data on digital technology usage and digital literacy.

\subsection{Data Collection}

Two survey questionnaires were designed to gather information pertaining to the objective of the study. A pilot test study was conducted to test the consistency and reliability of the survey. The Cronbach Alpha values were higher than 0.6, which is the accepted level. The authors of [33] suggested that a value of 0.6 to 0.7 is acceptable, while 0.8 or greater is very ideal. Each survey included three sections, which were demographic information, using digital technologies for learning/teaching practices, and digital literacy. The survey included 34 items for using digital technology for learning/teaching and 10 items for digital literacy. Questionnaires were distributed to the respondents for data collection. As it was a web-based survey, the questionnaire was distributed to the respondents through Google Form. This promotes convenience to researchers and respondents as they could answer the questionnaire through their electronic gadgets no matter where they were.

\subsection{Data Analyses}

Exploratory factor analyses were performed to evaluate the validity and reliability of the survey. The findings are presented in Table 1. The results show that the Kaiser-MeyerOlkin Measure of Sampling Adequacy (KMO) values exceeded the recommended value of 0.6. Bartlett's Test of Sphericity was accepted and reached a significance level $p<0.00$. These findings indicate that the collected data was suitable for factor analysis.

The result for the principal component analysis revealed the presence of only one component with an eigenvalue exceeding 1 in each section. This was further supported by the results of parallel analysis, which depicted only one component with an eigenvalue exceeding the criterion value from the parallel analysis. Both results confirm the unidimensionalality of teachers' and students' surveys. In the factor loadings of the items in students' and teachers' questionnaires, all items have factor loading above the minimum significant loading 0.40 , [34] ranging from 0.664 to 0.969 for students' surveys and from 0.582 to 0.972 for teachers' surveys. None of the items had more than one significant loading (cross-loading). In addition, each item has a communality value that exceeds the cutoff point of 0.30 (Pallant 2011). Furthermore, the items show high internal consistency with a Cronbach Alpha value of 0.854 which is well above the recommended level of 0.70 . This shows that the items measuring the same underlying construct, and therefore all items, are retained for confirmatory factor analysis. Furthermore, the items in the two questionnaires show high internal consistency, with Cronbach Alpha values exceeding the recommended level of 0.70 . This shows that the items are measuring the same underlying construct and the survey is suitable for data collection. The normality test for variables was carried out using Kolmogorov-Smirnov and Shapiro-Wilk W tests. The variables are normally distributed, as the $p$-value of the test was less than the predefined amount of 0.05 . 
Table 1. Results of KMO and Bartlett test of sphericity.

\begin{tabular}{|c|c|c|c|c|}
\hline \multirow[t]{2}{*}{ Variable } & \multirow[t]{2}{*}{ KMO } & \multirow[b]{2}{*}{ Approximate Chi-Squared } & \multicolumn{2}{|c|}{ Bartlett's Test of Sphericity } \\
\hline & & & DF & Sig \\
\hline \multicolumn{5}{|c|}{ Students' Survey } \\
\hline General learning purposes & 0.792 & 222.801 & 6 & 0.000 \\
\hline Listening & 0.738 & 286.396 & 6 & 0.000 \\
\hline Speaking & 0.781 & 304.812 & 6 & 0.000 \\
\hline Writing & 0.838 & 522.920 & 6 & 0.000 \\
\hline Vocabulary & 813 & 561.138 & 6 & 0.000 \\
\hline Reading & 725 & 878.808 & 6 & 0.000 \\
\hline Basic digital Literacy & 0.757 & 553.320 & 10 & 0.000 \\
\hline Didactic digital literacy & 0.833 & 502.926 & 10 & 0.000 \\
\hline \multicolumn{3}{|c|}{ Teachers' Survey } & & 0.000 \\
\hline General teaching purposes & 0.801 & 73.756 & 6 & 0.000 \\
\hline Listening & 0.779 & 89.590 & 6 & 0.000 \\
\hline Speaking & 0.523 & 27.764 & 6 & 0.000 \\
\hline Writing & 0.600 & 42.038 & 6 & 0.000 \\
\hline Vocabulary & 0.748 & 114.310 & 6 & 0.000 \\
\hline Reading & 0.643 & 100.317 & 6 & 0.000 \\
\hline Basic digital Literacy & 0.810 & 110.735 & 10 & 0.000 \\
\hline Didactic digital literacy & 0.745 & 118.173 & 10 & 0.000 \\
\hline
\end{tabular}

The demographic information of the students showed that $56.7 \%$ of them are male respondents while $43.3 \%$ are female. Most of the respondents are between 15-16 years old, at a total of $82(54.7 \%)$, followed by the respondents which are 16-17 years old, at a total of $68(45.3 \%)$ The respondents prefer modern teaching styles (Technology-enhanced learning) where the average was $80 \%$, while the conventional style of teaching is favored by $20 \%$. Teachers' demographic information showed that 25 (62.5\%) of them are male respondents, and $15(37.5 \%)$ are female respondents. Most of the respondents are between 30-40 years old at a total of $21(52.5 \%)$, followed by the respondents between 20-30 years old at a total of $12(30 \%)$, followed by the respondents between $40-50$ years old at a total of $4(10 \%)$, and 3 respondents were above 51 years old $(7.5 \%)$. In terms of formal ICT education, $90 \%$ of respondents had no formal ICT education while only $10 \%$ had ICT training. A total of $90 \%$ of teachers engaged with digital technologies in their teaching practices. This high percentage is due to the shift to remote learning because of the COVID-19 pandemic.

Prescreening of the data was performed during primary data collection. We checked that no questions were left incomplete upon collection of each questionnaire answer. In this study, the statistical software version 23 of the Statistical Package for Social Sciences (SPSS) was used. Descriptive analyses were used not only for descriptive purposes but also to assess the relationships at the point of inquiry between variables. The mean scores of the subjects' responses for each question range from 1-5, specifically based on the measuring criteria offered by Hanson et al. [35]. Specifically, the mean scores of agreements ranging from 1.00 to 2.33 are construed as low, 2.34 to 3.67 are construed as moderate and mean scores of agreements range from 3.68 to 5.00 are construed as high. The independent sample t-test was used to investigate the significant difference between the respondents.

\section{Results}

\subsection{Students' Use of Digital Technologies}

\subsubsection{Digital Technologies for General Learning Purposes}

The students agree on using digital technologies for general learning purposes with a total mean of 3.84. This indicates that students approve they are using digital technologies for their general learning purposive. The students highly agreed on "I use digital technologies for English research projects papers, essays, etc." with $\mathrm{M}=3.93$, "I use digital technologies for my English studies assignments and practice" $\mathrm{M}=3.89$, "I use digital 
technologies to discuss their English assignments with teachers via emails" $M=3.84$, and "I use digital technologies in searching for online English learning materials" $\mathrm{M}=3.71$.

\subsubsection{Digital Technologies for Learning Listening}

The students agreed that "they use (YouTube, Netflix) to improve their listening skills" with $\mathrm{M}=4.33$. The extensive use of these platrorms is justified by the fact that they are known for their popularity and ease of use. For "use digital audiobooks to improve my listening skills", $M=3.69$. However, the students showed moderate agreement on "listen to (podcast, radio) to improve my listening skills", with $\mathrm{M}=3.15$, and "watch News channels in English to improve speaking skills" with $\mathrm{M}=3.62$. The high agreement on the use of digital technologies indicates the usefulness of these digital technologies in improving listening skills.

\subsubsection{Digital Technologies for Learning Speaking}

The students highly agreed on "I use online applications such as (Skype, zoom) to practice speaking" $\mathrm{M}=3.93$, and "I interact with native speakers through special learning website to improve my speaking skills" $\mathrm{M}=3.91$. On the other hand, a moderate agreement was revealed on the "use of google meet to practice speaking with my friends" with a mean (3.88). There was moderate agreement in "I use Voice recognition apps (Moodle, Busu, Rosetta Stone) to check my pronunciation" $\mathrm{M}=3$. Students' high agreement on using "Skype, Zoom, and Google meet" to learn and improve speaking skills could be justified by these applications being widely used among students, where students can have video calls to learn and check pronunciation from each other.

\subsubsection{Digital Technologies for Learning Writing}

The students agreed that they "use "Grammarly, grammar checker" to check my writing" $\mathrm{M}=4.07$, "use collaborative writing tools like Google docs to share my writing draft with friends" $\mathrm{M}=3.96$, "use digital games chat rooms to practice writing in English" $\mathrm{M}=3.87$. Additionally, the respondents showed high agreement in "use writingenhancement platforms to improve my writing skills" $M=3.87$. There was moderate agreement on "use digital applications like "StoryToolz" and "Zotero" applications to practice writing". The high mean scores of using Grammarly and grammar checker and games chat rooms indicate the usefulness of digital technologies in learning writing.

\subsubsection{Digital Technologies for Learning Vocabularies}

The students agreed that they "use e-dictionaries to learn new words" with $\mathrm{M}=3.96$, "Read e-books to learn new vocabularies" $\mathrm{M}=3.95$, "use games such as (Cross Words, Puzzles, Word finder) to enhance my vocabulary competence" $\mathrm{M}=3.95$, and "using web-based flashcards to learn new" $\mathrm{M}=3.94$. In general, the findings show that digital technologies are highly used by EFL students to learn vocabulary.

\subsubsection{Digital Technologies for Learning Reading}

The responses of students approved that they "use E-book to read English books to enhance my reading skills" $M=4.00$. Additionally, the students showed high agreement, 3.65 , in "use online learning websites to improve my reading skills" $\mathrm{M}=3.70$. However, the students showed moderate agreement on "I read online magazines and newspapers to improve my reading skills" $\mathrm{M}=3.45$. On the other hand, the students showed low agreement on "use digital applications such as Newsela to enhance my reading skills" $\mathrm{M}=3.65$. In general, the findings showed a moderate level of using digital technologies for learning to speak, which indicate that students need more literacy and knowledge on how to use modern application and websites such as "Newsella" to learn and improve reading skills. 


\subsection{Teachers' Use of Digital Technologies}

\subsubsection{Digital Technologies for General Teaching Practices Skills}

The total high mean score indicates that teachers use digital technologies for general teaching practices with a total of $\mathrm{M}=4.14$. The views of teachers showed thar they "use digital technologies to discuss their English assignments with my students" $M=4.25$, "use digital technologies for marking students' research projects papers, essays, etc" $M=4.25$, "use digital technologies for their English teaching practice" $M=4.02$, "use digital technologies to search for online teaching materials" $\mathrm{M}=4.05$. In general, all answers from teachers showed high agreement to confirm the high level of using digital technology for digital teaching purposes.

\subsubsection{Digital Technologies for Teaching Listening Skills}

Teachers showed high agreement on using digital technologies for listening, with a high total mean of 3.94. Teachers' responses showed the highest agreement on "I use YouTube to improve my students' listening skills", with $M=4.05$. Additionally, there was high agreement on "I ask my students to watch News channels in English to improve my students' speaking skills" with $\mathrm{M}=4.00$. Furthermore, teachers showed high agreement, at $\mathrm{M}=3.90$, for "use digital audiobooks to improve my students' listening skills" and high agreement, with $\mathrm{M}=3.83$, for "I play podcast and radio to improve my students' listening skills". In general, the findings indicate that teachers are aware of the importance of using digital technologies in improving students' skills, especially listening, as one of the most important skills.

\subsubsection{Digital Technologies for Teaching Speaking Skills}

The high mean score of 3.94 indicates that teachers are using digital technologies to teach and improve students' speaking skills. The teachers agree on "I use online applications such as Skype, zoom, google meet to practice speaking with my students" with $\mathrm{M}=4.03$, "I encourage my students to interact with native speakers through special learning websites" $\mathrm{M}=4.10$, and "I use Cambridge incognito application to improve my students' speaking skills" with $M=3.60$. A moderate level of usage was reported by teachers on "use Voice recognition apps such as Busu to improve students' pronunciation", with $M=3.65$. In line with previous findings, teachers are using digital technologies to improve their students' speaking skills.

\subsubsection{Digital Technologies for Teaching Writing Skills}

The high mean score of 3.93 indicates that teachers are using digital technologies to teach and improve their students' writing skills. Teachers showed a high level of agreement on "I use Grammarly and grammar checker to help my students improve their writing skills", with $\mathrm{M}=4.10$, "I encourage my students to write English in games chat rooms" $\mathrm{M}=4.08$, "use collaborative writing tools like Google docs to share writing drafts with students" with $\mathrm{M}=4.02$, and "I use digital apps such as Duolingo to improve my students" writing skills" with $\mathrm{M}=3.53$. The high, overall mean score indicates that teachers believe in the significant role of digital technologies in improving students' writing skills.

\subsubsection{Digital Technologies for Teaching Vocabularies}

The total, high mean score of 4.13 indicates that teachers have a high level of using digital technologies to teach and improve students' English vocabularies. Teachers showed a high agreement on "use gamifying such as Cross Words, puzzles and Word finder to enhance my students' vocabulary", with $\mathrm{M}=4.20$, "I use web-based flashcards to help my students learn new vocabularies" at $\mathrm{M}=4.18$, "use digital dictionaries to help my students learn new vocabularies" with $\mathrm{M}=4.10$, and "use e-books with their students to learn new vocabularies" at $M=4.05$. In general, all the items were responded to by teachers with high agreement, which indicates that several digital technologies can assist 
in improving students' vocabulary competence, and teachers are using multiple kinds of digital technologies to improve students' vocabularies.

\subsubsection{Digital Technologies for Teaching Reading}

The total, high mean score of 3.67 indicates that teachers have a high level of using digital technologies to teach and improve students' reading skills. Teachers showed high agreement on "use online learning websites to improve my students' reading skills", with $\mathrm{M}=3.90$, "use the e-book to read English books to enhance their students' reading skills" at $\mathrm{M}=3.65$, and "I ask my students to read online magazines and newspapers to improve their reading skills" at $\mathrm{M}=3.80$. On the other hand, teachers moderately agree on "use digital applications such as Newsella to enhance students' reading comprehension", with $\mathrm{M}=3.38$. It can be concluded that digital technologies are playing a key role in improving students' reading, as teachers showed a high level of using digital technologies in teaching reading.

\subsection{Comparison of Teachers' and Students' Use of Digital Technologies}

Table 2 below compares the mean scores of teachers' and students' use of digital technologies for teaching and learning purposes. Based on the results, there is a slight difference between students' and teachers' use of digital technology. Teachers showed a higher level of using digital technologies, with a total mean score of 3.91, and students of 3.81. Furthermore, it can be noticed that teachers' highest level of using digital technology is for general teaching purposes, while students' highest level of using digital technologies is for learning vocabulary. On the other hand, both teachers and students showed the lowest level of digital technologies for teaching and learning reading skills. The justification of these results is that education 4.0, which is defined as using technology in teaching and learning, requires teachers and students to use digital technologies to stay up to date with modern teaching methods and learning styles. Moreover, teachers and students are left with no choice but to use digital technologies for online learning because of the schools ${ }^{\prime}$ closure to stop the spread of COVID-19 in Malaysia. This has created a leapfrog in the use of digital technologies in education in general, and in language learning in particular.

Table 2. Comparison between teachers' and students' use of digital technologies.

\begin{tabular}{cccc}
\hline Construct & Students MS & Teachers MS & Criteria \\
\hline General purposes & 3.84 & 4.14 & High \\
Listening & 3.69 & 3.94 & High \\
Speaking & 3.89 & 3.94 & High \\
Writing & 3.89 & 3.93 & High \\
Vocabulary & 3.95 & 4.13 & High \\
Reading & 3.60 & 3.67 & Moderate \\
\hline
\end{tabular}

\subsection{Digital Literacy}

\subsubsection{Students' Basic Digital Literacy}

The total mean of 4.26, which is categorized as "high", indicates that students have high basic digital-literacy skills. The students showed high agreement on, "I can recognize and manage digital resources such as create folders, links, and favorites", with $\mathrm{M}=4.00$, "I can use learning management systems (LMS) like Moodle" with $\mathrm{M}=3.92$, "can use, access, and locate the information I need to learn English language" with $\mathrm{M}=3.91$, "I can use search engines (Google, ping) to look learning materials" with $\mathrm{M}=3.90$, and "I can use communication and presentation tools" with $\mathrm{M}=3.87$. In general, it can be seen that students have a high level of basic digital-literacy skills and they can use digital technologies.

\subsubsection{Students' Didactic Digital Literacy}

The high total mean score of 4.24 indicates that students posit a high level of didactic digital-literacy skills. Students showed high agreements on "I can use technologies to 
support learning across boundaries of time and space", with $\mathrm{M}=4.29$, "I use modern apps like zoom and google meet in attending online in the English language classes", with $\mathrm{M}=4.27$, "I can use google docs and google classroom to share information", with $\mathrm{M}=4.27$, "I can participate in a digital academic meeting through zoom or google meeting to enhance my language", with $\mathrm{M}=4.18$, and "I like to use the modern technology-based learning style" at $\mathrm{M}=4.18$. In general, it can be concluded that students posit a high level of skills regarding the use of digital literacies for pedagogical purposes.

\subsubsection{Teachers' Basic Digital Literacy}

The total mean of 3.92, which is categorized as "high", indicates that teachers have a high level of basic digital-literacy skills. The teachers showed high agreements on, "I can use, access, and locate the information I need to use", with $\mathrm{M}=4.30$, "I can recognize and manage digital resources such as create folders, links, and favorites", with $\mathrm{M}=4.23$, "I can use learning management systems (LMS) like Moodle", with $\mathrm{M}=4.23$, "I can use communication and presentation tools", with $\mathrm{M}=4.18$, and "can use search engines (Google, Ping)", at $\mathrm{M}=4.17$. In general, it can be concluded that teachers have a high level of skills regarding the use of digital technologies for general purposes.

\subsubsection{Teachers' Didactic Digital Literacy}

The high total mean score indicates that teachers have a high level of didactic digitalliteracy skills. Teachers showed high agreements on "I can participate in a digital academic meeting through zoom or google meeting to deliver classes", with $\mathrm{M}=4.43$, "I have used modern apps like zoom and google meet in attending online in the English language classes", with $\mathrm{M}=4.37$, "I like to use the modern technology-based learning style", with $\mathrm{M}=4.37$, "I can use technologies to support learning across boundaries of time and space", with $\mathrm{M}=4.23$, and "I can use google docs and google classroom to share information" at $\mathrm{M}=4.20$. Hence, it can be concluded that teachers posit a high level of skills regarding use of digital literacies for pedagogical purposes.

\subsubsection{Comparison of Students' and Teachers' Digital Literacy}

Both students and teachers posit high levels of digital-literacy skills and didactic digital-literacy skills. However, teachers have a higher level of digital-literacy skills than students for basic digital-literacy skills and didactic digital-literacy skills. Additionally, it can be noticed that both teachers and students have higher levels of didactic digital-literacy skills than basic digital literacy. These results are justified by the fact that teachers and students acquired these skills by the high level of direct exposure to digital technologies through conducting and attending online classes after schools' closure and the shift of education to remote learning. The findings are presented in Table 3.

Table 3. Comparison between teachers' and students' digital literacy.

\begin{tabular}{cccc}
\hline Construct & Students MS & Teachers MS & Criteria \\
\hline Basic digital literacies & 3.92 & 4.24 & High \\
Didactic Digital Literacies & 4.22 & 4.33 & High \\
\hline
\end{tabular}

\subsection{Hypotheses Testing}

\subsubsection{Digital Technology Usage}

As shown in Table 4, the independent t-test shows that all the variables showed no significant difference as follows: using digital technologies for general purposes " 0.054 ", using digital technologies for teaching/learning listening " 0.061 ", using digital technologies for teaching/learning speaking " 0.763 ", using digital technologies for teaching/learning writing " 0.617 ", using digital technologies for teaching or learning vocabulary " 0.270 ", and using digital technologies for teaching or learning reading " 0.589 ". Therefore, based on the criteria of $(p>0.05)$, if the $p$-value is higher than 0.05 this indicates that there is no significant 
difference between the samples (teachers/students), and it can be concluded that the null hypotheses regarding the use of digital technologies for teaching and learning English using digital technologies are supported and the alternative hypotheses are rejected.

Table 4. Hypotheses testing of digital technology usage.

\begin{tabular}{|c|c|c|c|c|c|c|c|c|}
\hline \multirow{2}{*}{ Construct } & \multirow[t]{2}{*}{ Respondents } & \multirow[t]{2}{*}{$n$} & \multirow{2}{*}{ M. Diff } & \multicolumn{2}{|c|}{$\begin{array}{c}\text { Levene's Test for } \\
\text { Equality of Variance }\end{array}$} & \multirow{2}{*}{$\begin{array}{l}\text { Std. Error } \\
\text { Diff }\end{array}$} & \multirow{2}{*}{$\mathbf{T}$} & \multirow[t]{2}{*}{ Sig } \\
\hline & & & & $\mathbf{F}$ & Sig & & & \\
\hline \multirow{2}{*}{$\begin{array}{c}\text { General Learning } \\
\text { Purposes }\end{array}$} & Students & 150 & \multirow{2}{*}{0.2975} & \multirow{2}{*}{14.638} & \multirow{2}{*}{0.000} & \multirow{2}{*}{0.150} & \multirow{2}{*}{1.974} & \multirow{2}{*}{0.054} \\
\hline & Teachers & 40 & & & & & & \\
\hline \multirow{2}{*}{ Listening } & Students & 150 & \multirow{2}{*}{0.2537} & \multirow{2}{*}{0.965} & \multirow{2}{*}{0.327} & \multirow{2}{*}{0.132} & \multirow{2}{*}{1.913} & \multirow{2}{*}{0.061} \\
\hline & Teachers & 40 & & & & & & \\
\hline \multirow{2}{*}{ Speaking } & Students & 150 & \multirow{2}{*}{0.0458} & \multirow{2}{*}{65.436} & \multirow{2}{*}{0.00} & \multirow{2}{*}{0.151} & \multirow{2}{*}{0.303} & \multirow{2}{*}{0.763} \\
\hline & Teachers & 40 & & & & & & \\
\hline \multirow{2}{*}{ Writing } & Students & 150 & \multirow{2}{*}{0.0725} & \multirow{2}{*}{0.876} & \multirow{2}{*}{0.350} & \multirow{2}{*}{0.144} & \multirow{2}{*}{0.503} & \multirow{2}{*}{0.617} \\
\hline & Teachers & 40 & & & & & & \\
\hline \multirow{2}{*}{ Vocabulary } & Students & 150 & \multirow{2}{*}{0.1795} & & & & & \\
\hline & Teachers & 40 & & 0.94 & 0.760 & 0.161 & 1.113 & 0.210 \\
\hline Dondin & Students & 150 & & & & & & \\
\hline Keaumg & Teachers & 40 & 0.0812 & 0.190 & $0.3 / 4$ & 0.149 & 0.543 & 0.589 \\
\hline
\end{tabular}

Significance level: $p<0.05$.

\subsubsection{Digital Literacy}

This section presents the findings of hypotheses of digital literacies in using digital technology for teaching and learning purposes. To test the hypotheses, the independent $\mathrm{t}$-test was used. The results are presented in Table 5. As the table shows, the independent t-test results show that the significance level for basic digital-literacy skills between teachers and students is " 0.142 ", and didactic digital-literacy skills is " 0.597 ". This means that there are no significant differences between teachers and students in basic and didactic digital literacy. Therefore, based on the criteria of $(p<0.05)$, if the $p$-value is higher than 0.05 this indicates no significant differences between the samples (teachers/students), and it can be concluded that the null hypotheses regarding the basic and didactic digital literacies of using digital technologies are supported and the alternative hypotheses are rejected.

Table 5. Hypotheses testing of digital literacies.

\begin{tabular}{|c|c|c|c|c|c|c|c|c|}
\hline \multirow{2}{*}{ Construct } & \multirow{2}{*}{ Respondents } & \multirow{2}{*}{$n$} & \multirow{2}{*}{ M. Diff } & \multicolumn{2}{|c|}{$\begin{array}{c}\text { Levene's Test for } \\
\text { Equality of Variance }\end{array}$} & \multirow{2}{*}{$\begin{array}{l}\text { Std. Error } \\
\text { Diff }\end{array}$} & \multirow[t]{2}{*}{$\mathbf{T}$} & \multirow{2}{*}{ Sig } \\
\hline & & & & F & Sig & & & \\
\hline \multirow{2}{*}{$\begin{array}{l}\text { Basic Digital } \\
\text { Literacies }\end{array}$} & Students & 150 & \multirow{2}{*}{0.28000} & \multirow{2}{*}{0.152} & \multirow{2}{*}{0.697} & \multirow{2}{*}{0.129} & \multirow{2}{*}{2.166} & 0.142 \\
\hline & Teachers & 40 & & & & & & \\
\hline \multirow{2}{*}{$\begin{array}{l}\text { Didactic Digital } \\
\text { Literacies }\end{array}$} & Students & 150 & \multirow{2}{*}{-0.31500} & \multirow{2}{*}{4.40} & \multirow{2}{*}{0.37} & \multirow{2}{*}{0.124} & \multirow{2}{*}{2.535} & \multirow{2}{*}{0.597} \\
\hline & Teachers & 40 & & & & & & \\
\hline
\end{tabular}




\section{Discussion}

The study was structured to investigate the use of digital technologies among EFL teachers and students for teaching and learning, and teachers and students' digital literacy. The high level of using digital technologies among EFL teachers and students present empirical evidence on the contributions of digital technologies towards enhancing language learning and teaching. This indicates that EFL teachers and students hold strong points of view about digital technologies. This could be attributed to the fact that the shifting educational context, especially during the COVID-19 period, reflects the progressive state of society in addition to the growing significance of digital technologies as well as technology-based teaching and learning in the era of the fourth industrial revolution, in the local and even at the global scale. Furthermore, the findings provide evidence that the digital technology used in education depends on important assumptions that the teachers and students need to have, which are the positive point of view and necessary digital literacies. The findings echoed with results from many previous studies. The high school students' digital technology uses outside of school surpassed their technology use inside of school $[36,37]$. Students use of digital technologies for learning "Google Drive, Blogs", assumed to be popular among digital natives, was found as popular as previously presumed [38,39].

Based on these findings, it can be seen that past research in the Arab EFL context conform to the results of high usage of digital technologies for teaching and learning listening [40], and [41] found that digital technology has improved students' listening skills. Regarding speaking skills, the findings of the study are in line with the findings reached by [42-44], who found that digital technologies have a positive impact on students' speaking skills. Al-Ahdal [44] used a computer software system to analyze students errors to improve students' speaking, Al-Saleem [42] found that Facebook activities enhanced students' oral communication, while Minalla [43] concluded that WhatsApp application chat groups developed students' verbal interactions, Hamad et al. [45] used the YouTube application to improve students speaking skills and concluded that YouTube has a positive impact on EFL students' speaking skills. Additionally, the findings of the writing skill are in line with the outcomes of the following past studies that have used the following digital technologies: weblog [41], screen-casting [46], wikis [47], flipped classroom [48], Facebook [49], portfolio [50], and WhatsApp [51]. The outcomes of these studies revealed that digital technologies have improved EFL students writing skills. In terms of vocabulary teaching and learning, the findings are associated with the results of the previous research conducted on mobile phones, data-driven learning, Telegram, application, Blackboard, games (Al Momani 2020), Telegram (Hassan Taj et al., 2017), and technology-enhanced learning [52-56]. These studies concluded that digital technologies help students in acquiring new vocabulary.

Finally, the results of using digital technologies in teaching and learning reading confirm the results of blogs and CALL $[57,58]$. These studies have shown that digital technologies improve students' reading skills. The results of the current study demonstrated that EFL teachers and students showed a high level of exposure to digital technologies for formal and informal uses. High exposure provides an easier integration of digital technology for pedagogical purposes. This could be attributed to the fact that during the data collection period, the education process was shifted to remote learning due to the schools' closure because of the COVID-19 pandemic. During this period, teachers and students used digital technologies for online classes. Higher exposure increases students' achievements, and these results go in line with [59], where it was found that higher exposure leads to higher achievements. Additionally, Ortiz et al. (2011) found that parents believe that using digital technologies may increase their children's academic achievement and future job opportunities. On the other hand, Kohnke [60] found that Facebook constitutes a virtual space where EFL learners can be exposed to English, it is commonly earmarked as a source of 'procrastination' and 'distraction'. Wang [61] goes a step further, claiming that online communication-Facebook a case in point-seems to be "trash forms of communication 
where good spelling and grammar are irrelevant." (p. 2). These findings could be justified by the fact that by the time of these published articles, Facebook and other digital technologies were in their infancy stage and were not used for pedagogical purposes.

The findings of the study contradict the results of Al-Qallaf \& Al-Mutairi [62], who found that even though teachers are enthusiastic about using digital technologies in teaching, they are still worried about their digital literacy. On the other hand, the findings parallel the results of Cote and Milliner [63,64], which indicated that Japanese and Indonesian English teachers are confident in using digital technology and are committed to improving their digital literacies. However, the results of digital literacy of students contradict most of the findings in the literature review, as many studies have reported a low level of digital literacy among EFL students. Studies found that even though the EFL students today are digital natives, they still lack digital knowledge and skills [65]. The results indicated that today's school-age learners are no more technology savvy than their teachers. The previous assumption used to profile students as digital natives [66] did not apply to the students in this study. Teachers' technology-use experiences surpassed students, whether inside or outside of school.

All the null hypotheses were supported considering the $p$-values. The results of the hypotheses testing indicate that teachers and students share the same usage of digital technologies for teaching and learning listening, speaking, writing, vocabulary, and reading. The justification for these results is that teachers and students share similar use and access to digital technologies in the class for teaching and learning-e-administration. Unlike the previous findings of the literature, students and teachers showed a similar level of literacies and skills for pedagogical literacies. This could be attributed to similar access to digital technologies for teaching and learning purposes. Based on the analysis, the study is consistent with $[67,68]$. These studies found no significance between students and teachers in terms of digital technologies used such as interactive whiteboards. However, these findings contradict the findings reported by [69-73], who concluded that there is a significant difference between EFL teachers and students in digital technology used for pedagogical purposes.

For a successful diffusion of technology into the English language curriculum, there should be a shift from the existing, traditional TEFL to the technology-based English learning paradigm. This shift necessitates a transformation from paper-based texts to electronic texts (e-texts). The shift should be directed towards (a) designing software courses instead of or blended with the traditional textbooks, and (b) learning management systems (LMS) instead of the traditional classroom management. Unless English language education shifts to learner-centeredness, digital technology integration remains a daunting challenge. Guided by the nature of the digital technology-oriented paradigm, there should be a shift towards more engaged students (learner autonomy). For this to happen-and to rise to the challenge- there should be a shift from lecturing and recitation to coaching and training, and from talking about the language to using the language.

\section{Concluding Remarks}

The current study took place at Arab international schools in Malaysia, where the use of digital technologies and the level of digital literacy among EFL teachers and students use of digital technologies have not been explored enough by research in the Middle Eastern context in general, and Arab international schools in Malaysia in particular. The study used a quantitative research design to collect data from $150 \mathrm{EFL}$ students and $40 \mathrm{EFL}$ teachers. The results revealed a high level of using digital technologies by EFL teachers and students. Additionally, teachers and students have a high level of basic and didactic digital literacies. Additionally, the study showed that there are no significant differences between students and teachers' use of digital technologies. The main limitation of this study stemmed from the research setting, where the 'digital divide' was an imposed factor; it defined the scope and methodology of the investigation. The participants come from a traditional textbook orientation, with a deeply entrenched belief in note memorization 
as a good way of teaching and learning. Hence, it was impractical to successfully adopt ICT-based research tools with the sample. Hence, the study used tools and procedures that fitted with the existing low-tech learning settings. Using a fully quantitative research design, the study recommends that future research may use interviews and observation to compare the actual use of digital technologies by the teachers, and also take a close look at the engagement between the teachers and the students in EFL class to explore when, why and in what ways digital technology is being implemented. Theoretically, this study provides additional empirical support by modifying and extending the existing models and theories, as it extends its application to the use of digital technology in classes and a new context.

Author Contributions: Conceptualization, H.M.A. and N.A.R.; methodology H.M.A. and N.A.R.; software analyses, H.M.A. and N.A.R.; validation, H.M.A. and N.A.R.; data curation, N.A.R.; writingoriginal draft preparation, H.M.A.; writing—review and editing, N.A.R.; supervision, N.A.R. All authors have read and agreed to the published version of the manuscript.

Funding: This research received funding from the Ministry of Higher Education, Malaysia, under the project "Modelling of B40 Women Entrepreneurs for Economic Wellbeing in the Digital Economy System". The fund number LRGS/1/2020/UKM-UKM/01/5/2.

Institutional Review Board Statement: The study was conducted according to the guidelines of the Universiti Kebangsaan Malaysia, and approved by the Ethics Committee of Faculty of Social Sciences and Humanities, 2020.

Informed Consent Statement: Informed consent was obtained from all subjects involved in the study.

Conflicts of Interest: The authors declare no conflict of interest.

\section{References}

1. Elwood, J.; MacLean, G. ICT Usage and Student Perceptions in Cambodia and Japan. Int. J. Emerg. Technol. Soc. 2009, 7, 65-82.

2. Chang, C.-K.; Hsu, C.-K. A mobile-assisted synchronously collaborative translation-annotation system for English as a foreign language (EFL) reading comprehension. Comput. Assist. Lang. Learn. 2011, 24, 155-180. [CrossRef]

3. Gilakjani, A.P.; Leong, L.-M.; Sabouri, N.B. A Study on the Role of Motivation in Foreign Language Learning and Teaching. Int. J. Mod. Educ. Comput. Sci. 2012, 7, 9-16. [CrossRef]

4. Raman, A.; Mohamed, A.H. Issues of ICT Usage among Malaysian Secondary School English Teachers. Engl. Lang. Teach. 2013, 6, 74-82. [CrossRef]

5. Elyas, T.; Picard, M. Saudi Arabian educational history: Impacts on English language teaching. Educ. Bus. Soc. Contemp. Middle East. Issues 2010, 3, 136-145. [CrossRef]

6. Hol, D.; Aydin, I. Is Technology in Our Classrooms? EFL Teachers' Beliefs and Engagement with Technology in the Classroom. J. Educ. Issues 2020, 6, 38-58. [CrossRef]

7. Alakrash, H.M.; Razak, N.A.J.C. Education and the fourth industrial revolution: Lessons from COVID-19. Comput. Mater. Contin. 2021, 70, 951-962. [CrossRef]

8. Alakrash, H.M.; Razak, N.A. Redesigning the English Classroom Towards Fourth Industrial Revolution, Are the Students Motivated. Asian ESP J. 2020, 6. Available online: https://www.researchgate.net/publication/345240886 (accessed on 26 October 2021).

9. Sayaf, A.; Alamri, M.; Alqahtani, M.; Al-Rahmi, W. Information and Communications Technology Used in Higher Education: An Empirical Study on Digital Learning as Sustainability. Sustainability 2021, 13, 7074. [CrossRef]

10. Choi, L.; Chung, S.J.S. Navigating Online Language Teaching in Uncertain Times: Challenges and Strategies of EFL Educators in Creating a Sustainable Technology-Mediated Language Learning Environment. Sustainability 2021, 13, 7664. [CrossRef]

11. Rahman, S.A.; Yunus, M.M.; Hashim, H. Applying UTAUT in Predicting ESL Lecturers Intention to Use Flipped Learning. Sustainability 2021, 13, 8571. [CrossRef]

12. Hussin, S.; Manap, M.R.; Amir, Z.; Krish, P. Mobile Learning Readiness among Malaysian Students at Higher Learning Institutes. Asian Soc. Sci. 2012, 8, 276-283. [CrossRef]

13. Jamalai, M.; Krish, P. Fostering 21st century skills using an online discussion forum in an English for specific purpose course. Malays. J. Learn. Instr. 2021, 18, 219-240. [CrossRef]

14. Li, J.-P.; Mirza, N.; Rahat, B.; Xiong, D. Machine learning and credit ratings prediction in the age of fourth industrial revolution. Technol. Forecast. Soc. Chang. 2020, 161, 120309. [CrossRef]

15. Levy, M. Technologies in use for second language learning. Mod. Lang. J. 2009, 93, 769-782. [CrossRef]

16. Plonsky, L.; Ziegler, N. The CALL-SLA interface: Insights from a second-order synthesis. Lang. Learn. Technol. 2016, 20, 17-37.

17. Blake, R. Technology and the four skills. Lang. Learn. Technol. 2016, 20, 129-142. 
18. Marinoni, G.; Van't Land, H.; Jensen, T. The Impact of Covid-19 on Higher Education around the World; IAU Global Survey Report; International Association of Universities: Paris, France, 2020.

19. Mseleku, Z. A literature review of E-learning and E-teaching in the era of Covid-19 pandemic. SAGE 2020, 57, 588-597.

20. Nash, C. Report on Digital Literacy in Academic Meetings during the 2020 COVID-19 Lockdown. Challenges 2020, 11, 20. [CrossRef]

21. Røkenes, F.M.; Krumsvik, R.J. Prepared to teach ESL with ICT? A study of digital competence in Norwegian teacher education. Comput. Educ. 2016, 97, 1-20. [CrossRef]

22. Sánchez-Cruzado, C.; Santiago Campión, R.; Sánchez-Compaña, M. Teacher Digital Literacy: The Indisputable Challenge after COVID-19. Sustainability 2021, 13, 1858. [CrossRef]

23. Purnama, S.; Ulfah, M.; Machali, I.; Wibowo, A.; Narmaditya, B.S. Does digital literacy influence students' online risk? Evidence from Covid-19. Heliyon 2021, 7, e07406. [CrossRef] [PubMed]

24. Schwab, K. The Fourth Industrial Revolution; Currency: New York, NY, USA, 2017.

25. World Economic Forum. The Global Gender Gap Report; World Economic Forum: Geneva, Switzerland, 2017.

26. Henderson, M.; Selwyn, N.; Aston, R. What works and why? Student perceptions of 'useful' digital technology in university teaching and learning. Stud. High. Educ. 2017, 42, 1567-1579. [CrossRef]

27. Collins, A.; Halverson, R. Rethinking Education in the Age of Technology: The Digital Revolution and Schooling in America; Teachers College Press: New York, NY, USA, 2018.

28. Dudeney, G.; Hockly, N. ICT in ELT: How did we get here and where are we going? ELT J. 2012, 66, 533-542. [CrossRef]

29. Ertmer, P.A.; Ottenbreit-Leftwich, A.T. Teacher technology change: How knowledge, confidence, beliefs, and culture intersect. J. Res. Technol. Educ. 2010, 42, 255-284. [CrossRef]

30. Koehler, M.J.; Mishra, P.; Akcaoglu, M.; Rosenberg, J.M. The Technological Pedagogical Content Knowledge Framework for Teachers and Teacher Educators. ICT Integr. Teach. Educ. A Resour. Book 2013, 2-7. Available online: http:/ /www.matt-koehler. com/publications/Koehler_et_al_2013.pdf (accessed on 26 October 2021).

31. Hamat, A.; Embi, M.A.; Hassan, H.A. Mobile learning readiness among UKM lecturers. Procedia-Soc. Behav. Sci. 2012, 59, 406-410. [CrossRef]

32. Krejcie, R.V.; Morgan, D.W. Determining Sample Size for Research Activities. Educ. Psychol. Meas. 1970, 30, 607-610. [CrossRef]

33. Brown, J.D. The Cronbach alpha reliability estimate. JALT Test. Eval. SIG Newsl. 2002, 6, 17-19.

34. Fabrigar, L.R.; Wegener, D.T. Exploratory Factor Analysis; Oxford University Press: Oxford, UK, 2011.

35. Hanson, W.E.; Creswell, J.W.; Clark, V.L.P.; Petska, K.S.; Creswell, J.D. Mixed methods research designs in counseling psychology. J. Couns. Psychol. 2005, 52, 224. [CrossRef]

36. Clark, W.; Logan, K.; Luckin, R.; Mee, A.; Oliver, M. Beyond Web 2.0: Mapping the technology landscapes of young learners. J. Comput. Assist. Learn. 2009, 25, 56-69. [CrossRef]

37. Luckin, R.; Clark, W.; Graber, R.; Logan, K.; Mee, A.; Oliver, M. Do Web 2.0 tools really open the door to learning? Practices, perceptions and profiles of 11-16-year-old students. Learn. Media Technol. 2009, 34, 87-104. [CrossRef]

38. Means, B.; Toyama, Y.; Murphy, R.; Bakia, M.; Jones, K. Evaluation of Evidence-Based Practices in Online Learning: A Meta-Analysis and Review of Online Learning Studies; Association for Learning Technology: Oxford, UK, 2009.

39. Hinostroza, J.E.; Labbé, C.; Brun, M.; Matamala, C. Teaching and learning activities in Chilean classrooms: Is ICT making a difference? Comput. Educ. 2011, 57, 1358-1367. [CrossRef]

40. Ahmad, S.Z. The Flipped Classroom Model to Develop Egyptian EFL Students' Listening Comprehension. Engl. Lang. Teach. 2016, 9, 166. [CrossRef]

41. Mohamed, M.M.K. Using audiobooks for developing listening comprehension among Saudi EFL prepar-atory year students. J. Lang. Teach. Res. 2018, 9, 64-73. [CrossRef]

42. AlSaleem, B.I. The Effect of Facebook Activities on Enhancing Oral Communication Skills for EFL Learners. Int. Educ. Stud. 2018, 11, 144. [CrossRef]

43. Minalla, A.A. The Effect of WhatsApp Chat Group in Enhancing EFL Learners' Verbal Interaction outside Classroom Contexts. Engl. Lang. Teach. 2018, 11, 1. [CrossRef]

44. Al-Ahdal, A. Using computer software as a tool of error analysis: Giving EFL teachers and learners a much-needed impetus. Int. J. Innov. Creat. Chang. 2020, 12. Available online: https://ssrn.com/abstract=3570619 (accessed on 26 October 2021).

45. Hamad, M.M.; Metwally, A.A.; Alfaruque, S.Y. The Impact of Using YouTubes and Audio Tracks Imitation YATI on Improving Speaking Skills of EFL Learners. Engl. Lang. Teach. 2019, 12, 191-198. [CrossRef]

46. Ghosn-Chelala, M.; Al-Chibani, W. Screencasting: Supportive feedback for EFL remedial writing students. Int. J. Inf. Learn. Technol. 2018, 35. [CrossRef]

47. Alghasab, M.; Hardman, J.; Handley, Z. Teacher-student interaction on wikis: Fostering collaborative learning and writing. Learn. Cult. Soc. Interact. 2019, 21, 10-20. [CrossRef]

48. Qader, R.O.; Yalcin Arslan, F. The Effect of Flipped Classroom Instruction in Writing: A Case Study with Iraqi EFL Learners. Teach. Engl. Technol. 2019, 19, 36-55.

49. Razak, N.A.; Saeed, M.A. EFL Arab Learners' Peer Revision of Writing in a Facebook Group: Contributions to Writ-ten Texts and Sense of Online Community. Engl. Lang. Teach. 2015, 8, 11-26. [CrossRef] 
50. Obeiah, S.F.; Bataineh, R.F. The effect of portfolio-based assessment on Jordanian EFL learners' writing performance. Bellaterra J. Teach. Learn. Lang. Lit. 2016, 9, 32-46. [CrossRef]

51. Kartal, G. What's up with WhatsApp? A critical analysis of mobile instant messaging research in language learning. Int. J. Contemp. Educ. Res. 2019, 6, 352-365. [CrossRef]

52. AbdulZahraa, S.F. The Effect of Using Mobile Phones for Learning New Vocabulary Items by Iraqi non-English Major College Students. Int. J. Innov. Creat. Chang. 2020, 14, 414-429.

53. Al-Mahbashi, A.; Noor, N.M.; Amir, Z. The effect of data driven learning on receptive vocab-ulary knowledge of Yemeni University learners. 3L Lang. Linguist. Lit. 2015, 21, 13-24.

54. Azmuddin, R.A.A.; Nor, N.F.M.; Hamat, A. Facilitating Online Reading Comprehension in Enhanced Learning Environment Using Digital Annotation Tools. IAFOR J. Educ. 2020, 8, 7-27. [CrossRef]

55. Alamer, H.A.H. Impact of Using Blackboard on Vocabulary Acquisition: KKU Students' Perspective. Theory Pract. Lang. Stud. 2020, 10, 598-603. [CrossRef]

56. Alfadil, M. Effectiveness of virtual reality game in foreign language vocabulary acquisition. Comput. Educ. 2020, 153, 103893. [CrossRef]

57. Wah, L.L.; Hashim, H. Determining Pre-Service Teachers' Intention of Using Technology for Teaching English as a Second Language (ESL). Sustainability 2021, 13, 7568. [CrossRef]

58. Maasum, T.N.R.T.M.; Mustaffa, R.; Stapa, S.H. Young Learners' Perceptions of Learning English Using Language Games in a Non-Formal Context. Mediterr. J. Soc. Sci. 2015, 6, 375. [CrossRef]

59. Delen, E.; Bulut, O. The Relationship between Students' Exposure to Technology and Their Achievement in Science and Math. Turk. Online J. Educ. Technol. TOJET 2011, 10, 311-317.

60. Kohnke, L.J. Honor as a Barrier in Adapting Technology in Language Learning Context in Oman. Theory Pract. Lang. Stud. 2011, 1, 1369-1374. [CrossRef]

61. Wang, S.-K.; Hsu, H.-Y.; Campbell, T.; Coster, D.C.; Longhurst, M. An investigation of middle school science teachers and students use of technology inside and outside of classrooms: Considering whether digital natives are more technology savvy than their teachers. Educ. Technol. Res. Dev. 2014, 62, 637-662. [CrossRef]

62. Al-Qallaf, C.L.; Al-Mutairi, A.S. Digital literacy and digital content supports learning: The impact of blogs on teaching English as a foreign language. Electron. Libr. 2016, 34. [CrossRef]

63. Cote, T.; Milliner, B. A Survey of EFL Teachers' Digital Literacy: A Report from a Japanese University. Teach. Engl. Technol. 2018, $18,71-89$.

64. Son, J.-B.; Robb, T.; Charismiadji, I. Computer literacy and competency: A survey of Indonesian teachers of English as a foreign language. Comput. Assist. Lang. Learn. Electron. J. 2011, 12, 26-42.

65. Supratman, L.P.; Wahyudin, A. Digital media literacy to higher students in Indonesia. Int. J. Engl. Lit. Soc. Sci. 2017,2 , 239217. [CrossRef]

66. Prensky, M. Digital wisdom and homo sapiens digital. In Deconstructing Digital Natives: Young People, Technology and the New Literacies; Taylor \& Francis Group: London, UK, 2011; pp. 15-29.

67. Mac Callum, K.S. Influences on the Adoption of Mobile Technology by Students and Teachers: A Thesis Presented in Partial Fulfilment of the Requirements for the Degree of Doctor of Philosophy in Information Systems at Massey University, Albany, New Zealand. Ph.D. Thesis, Massey University, Albany, New Zealand, 2011.

68. Öz, H. Teachers' and Students' Perceptions of Interactive Whiteboards in the English as a Foreign Language Classroom. Turk. Online J. Educ. Technol. TOJET 2014, 13, 156-177.

69. Moradi, K.; Sabeti, G. A comparison of EFL teachers and EFL students' understandings of 'highly effective teaching'. Procedia-Soc. Behav. Sci. 2014, 98, 1204-1213. [CrossRef]

70. Dashtestani, R. Implementing Mobile-Assisted Language Learning (MALL) in an EFL Context: Iranian EFL Teachers' Perspectives on Challenges and Affordances. JALT CALL J. 2013, 9, 149-168. [CrossRef]

71. Romero, C.A.T.; Ortiz, J.H.; Khalaf, O.I.; Prado, A.R. Business Intelligence: Business Evolution after Industry 4.0. Sustainability 2021, 13, 10026. [CrossRef]

72. Jha, N.; Prashar, D.; Khalaf, O.I.; Alotaibi, Y.; Alsufyani, A.; Alghamdi, S. Blockchain Based Crop Insurance: A Decentral-ized Insurance System for Modernization of Indian Farmers. Sustainability 2021, 13, 8921. [CrossRef]

73. Romero, C.T.; Castro, D.; Ortiz, J.; Khalaf, O.; Vargas, M. Synergy between Circular Economy and Industry 4.0: A Literature Review. Sustainability 2021, 13, 4331. [CrossRef] 